\title{
IQTISHODUNA
}

IQTISHODUNA: Jurnal Ekonomi Islam

E-ISSN: 2443-0056, P-ISSN: 2252-5661

Accredited Sinta 2 Number 148/M/KPT/2020

Volume 10 Issue 1, April 2021 | Page: 045-058

DOI: $\underline{\text { doi.org/10.36835/iqtishoduna.v10i1.945 }}$

\section{Esham, the Origin of Sukuk for Facing the Crisis: Historical Experience}

\author{
Khairunnisa Musari * \\ Departement of Islamic Economics, Postgraduate Program and Faculty of Islamic Business \\ Economics, Universitas Islam Negeri KH Ahmad Shiddiq Jember, Jl. Mataram No. 1 Karang \\ Miuwo Mangli Kec. Kaliwates Kabupaten Jember 68136, Indonesia
}

\begin{abstract}
Pandemic brings a crisis. This makes world leaders have to work hard and smartly in managing state budgets. During the heyday of Islam, Muslims also faced crises. Given that time the power of Islam mastered many areas of the world, it can be assumed that the crisis that occurred in the past was a global crisis as it is happening today. The difference is the crisis that occurred at the time because of losing the war. This paper tries to describe the historical experience of the esham, one of the fiscal instruments in the Islamic world that helped the Ottoman Empire overcome the crisis. Esham has mobilized low-cost funds from the public in a relatively concise time. Esham served as a better choice than looking for foreign debt. As the origin of sukuk, esham has simpler structure so that can be used as an alternative to sukuk with a lower cost. To deal with a crisis, esham may intervene in the economy. Esham funds to the real sector in turn will help the government drive the economy as well as control prices in the market for goods and services. Therefore, esham has the potential in facing the crisis.
\end{abstract}

Keywords: esham, sukuk, waqf, crisis, fiscal, Islamic finance.

Article History:

Received: January 11, 2021; Accepted: March 11, 2021; Published:

April 1, 2021

*Corresponding author: e-mail khairunnisamusari@yahoo.com

Paper type: Research paper

Cite this document: Musari, Khairunnisa. "Esham, the Origin of Sukuk for Facing the Crisis: Historical Experience", IQTISHODUNA: Jurnal Ekonomi Islam [Online], Volume 10 Number 1 (April 1, 2021)

Abstrak: Pandemi membawa krisis. Hal ini membuat para pemimpin dunia harus bekerja keras dan cerdas dalam mengelola anggaran negara. Pada masa kejayaan Islam, umat Islam juga menghadapi krisis. Mengingat saat itu kekuatan Islam menguasai banyak wilayah di dunia, maka dapat diasumsikan bahwa krisis yang terjadi di masa lalu merupakan krisis global seperti yang terjadi saat ini. Perbedaannya adalah krisis yang terjadi saat itu karena kalah perang. Tulisan ini mencoba memaparkan pengalaman sejarah esham, salah satu instrumen fiskal di dunia Islam yang membantu Kesultanan Utsmaniyah mengatasi krisis. Esham memobilisasi dana murah dari masyarakat dalam waktu yang relatif singkat. Esham menjadi pilihan yang lebih baik daripada mencari utang luar negeri. Sebagai asal mula sukuk, esham memiliki struktur yang lebih sederhana sehingga dapat digunakan sebagai alternatif sukuk dengan biaya yang lebih rendah. Untuk menghadapi krisis, esham dapat mengintervensi perekonomian. Dana esham untuk sektor riil pada gilirannya akan membantu pemerintah menggerakkan perekonomian sekaligus mengendalikan harga di pasar barang dan jasa. Oleh karena itu, esham memiliki potensi untuk mengatasi krisis.

Kata kunci: esham, sukuk, wakaf, krisis, fiskal, keuangan Islam 


\section{INTRODUCTION}

The severe and damaging impact of COVID-19 cannot be neglected. The pandemic has induced colossal loss of work in consequence of sudden mess in trade and economic activities. Economic growth has fallen due to underproduction capacity. If the demand shaking only has a minor effect on the output distortion from production capacity, it might be adapted by the market mechanism in the short term. If the shaking is major, it will conduct adaptation of the income level equilibrium. If the process is chronic and happens around the world, it could bring out a great recession. When the market mechanism abortive to work properly, the appropriate fiscal policies have to decide to avoid the drop of national income levels. ${ }^{1}$

One of the instruments of fiscal policy that provides the best response to pandemic shocks is the sukuk. Fitch Ratings explains that sovereigns are expected to stay the primary contributors to overall sukuk volumes when states confront widening fiscal deficits and high borrowing needs, caused by COVID19-related economic disruptions and lower oil prices. ${ }^{2}$

\footnotetext{
${ }^{1}$ Fauziah Zen and Fukunari Kimura, "Maintaining Fiscal Sustainability During the Pandemic Crisis", Economic Research Institute for ASEAN and East Asia (ERIA) Policy Brief, No. 2020-04 (June, 2020), 1.

2Fitch Ratings, "Sukuk Volumes Resilient to Coronavirus Stress", Fitch Ratings, Islamic Finance (October 21, 2020).
}

However, sukuk market has proved resilient to the impact of COVID-19. In the first nine months of the 2020, issuance reached a total of US $\$ 130.5$ billion, compared with US $\$ 127.3$ billion for the same period in 2019.3 In June 2020, the Government of Indonesia has raised US\$2.5 billion from a three-tranche global sukuk offering to help the government fund the fight against the COVID-19 pandemic. ${ }^{4}$

Regarding the existence of sukuk, no many literatures mention about esham as the origin of sukuk. Today, owing to financial engineering, most people know sukuk as a greatly fruitful instance of historical instruments. But, not many knows that sukuk actually reflects the modernity of two historical instruments, namely esham and cash waqf.

Therefore, it is important to introduce esham because financial engineering is currently starting to integrate sukuk with cash waqf. The combination of waqf and sukuk into a single contexture is currently being famous. There are currently two types of waqf and sukuk combination in the development, namely the cash waqf linked sukuk (CWLS) and the sukuk linked waqf (SLW). ${ }^{5}$ Both of

${ }^{3}$ Mustafa Adil, "2020: A Strong Year for Sukuk", Refinitiv, Investment Insight, (October 19, 2020).

${ }^{4}$ Adrian Wail Akhlas. "Govt Raises $\$ 2.5 \mathrm{~b}$ through Global Sukuk Offering to Address Pandemic Deficit", The Jakarta Post (June 18, 2020).

${ }^{5}$ Khairunnisa Musari, “The Evolution of Waqf and Sukuk toward Sukuk-Waqf in

46| Copyright $@$ 2021, IQTISHODUNA: Jurnal Ekonomi Islam

http://ejournal.iaisyarifuddin.ac.id/index.php/iqtishoduna 
them become the new blended finance for modern waqf instrument today. In Indonesia, CWLS is a new blended finance of fiscal instrument. ${ }^{6}$

Through historical research and library science, this conceptual paper attempts to introduce the historical experience of esham, a fiscal instrument in the Islamic world that helps the Ottoman Empire overcome the crisis. As the origin of sukuk, esham becomes a simpler instrument than sukuk so as is more appropriate for government borrowing. This paper believes that esham has potency as an alternative of Islamic finance to sukuk to cope with the crisis.

As a historical research, the majority of all academic writings on esham in this paper referring to the manuscript of Murat Çizakça ${ }^{7}$ and

Modern Islamic Economy", in International Journal of 'Umranic Studies, Vol. 2, Issue 1 (2019a, January), 47.

${ }^{6}$ Khairunnisa Musari, Cash Waqf Linked Sukuk, A New Blended Finance of Fiscal Instrument for Sustainable Socio-Economic Development: Lesson Learned from Indonesia, a paper was presented at $12^{\text {th }}$ International Conference on Islamic Economics and Finance (ICIEF) "Sustainable Development for Real Economy" with hosted by Istanbul Sabahattin Zaim University (IZU) and jointly organized by Islamic Research and Training Institute (IRTI) - Islamic Development Bank (IDB) and International Association of Islamic Economics (IAIE) with the collaboration of Statistical, Economic and Social Research and Training Centre for Islamic Countries (SESRIC) and Hamad Bin Khalifa University, Istanbul, (June 14-20, 2020), 1.

${ }^{7}$ Khairunnisa Musari, Esham for Fiscal Sustainability, An Alternative to Sukuk in Islamic Finance Perspective: Historical Experience, a paper was presented at taken from personal communication with him. Murat Çizakça is a Professor of Comparative Economic History and Islamic Finance at the Presidential Finance Office/Institute of Islamic Economics Marmara University, Istanbul and KTO Karatay University. $\mathrm{He}$ is also a Member of Academia Europaea and European Science Foundation.

\section{ESHAM IN HISTORY}

After the Ottoman Empire's tragic defeat by Russia in Crimea (1768-1774), as well as its ill-fated military clashes with France (1789) and Russia again (1792, 1812, and 1829), its institutions of public finance were no longer capable of supporting the basic functions of the state. During the fifty years that followed the disaster of 1774, the Ottomans launched radical experiments in public finance that were designed to centralize the government's fiscal operations and increase revenue for the treasury. In 1774 , the government introduced the esham. ${ }^{8}$

Esham is the plural form of sehm. ${ }^{9}$ In general, esham can be

Researcher Day "The 2019 International Conference on Fiscal Policy and InputOutput Modeling" at Auditorium of Fiscal Policy Agency Building, Ministry of Finance, Jakarta (August 28-29, 2019b), 2.

${ }^{8}$ Nadir Özbek, "Tax Farming in the

Nineteenth-Century Ottoman Empire: Institutional Backwardness or the Emergence of Modern Public Finance?", in The Journal of Interdisciplinary History, Vol. 49, No. 2, 224.

${ }^{9}$ Murat Çizakça, "Merging Waqf and Sukuk", in Journal of Islamic Economics, 
mentioned as a new system of domestic borrowing by the Ottoman government $^{10}$ or shares ${ }^{11}$. There is also who defines esham as a longterm domestic vehicle for borrowing, like a bond, that resembled the lifeterm annuities popular in many European countries at the time. ${ }^{12}$ But, there is also another explanation that esham was utilized by the Ottoman Empire to meet their shortterm financial needs until the $20^{\text {th }}$ century $^{13}$ or shares as public annuities which could be purchased by individuals of far lower incomes than the life-term tax farmers under new fiscal system ${ }^{14}$.

As a part of the fiscal policy by the Ottoman Empire, esham had been mobilized low-cost funds from the public in a concise time. This instrument proved effective to raise a rapidly massive amount of money from the public, ${ }^{15}$ particularly by incorporating small and medium size lenders. ${ }^{16}$ Esham controlled

Banking and Finance, Vol. 12, No. 3 (JulySeptember, 2016a), 103.

${ }^{10}$ Murat Birdal, The Political Economy of

Ottoman Public Debt, (London: Tauris Academic Studies, 2010), 23.

${ }^{11}$ Çizakça, "Merging Waqf..., p. 103.

${ }^{12}$ Özbek, Tax Farming, p. 224.

${ }^{13}$ Murat Çizakça, "Risk Sharing and Risk Shifting: An Historical Perspective", in Borsa Istanbul Review, Vol. 14, No. 4 (2014b), 193.

${ }^{14}$ Eliana Balla and Noel D. Johnson, "Fiscal Crisis and Institutional Change in the Ottoman Empire and France", in The Journal of Economic History, Vol. 69, No. 3 (September, 2009), 839.

${ }^{15}$ Musari, Esham for, p. 2.

16Sebnem Kalemli-Ozcan. 2007. Financial Development, Institutions, and Growth: Historical Evidence from the Ottoman public finance and enacted a pivotal role in the viability of the Ottoman Empire. ${ }^{17}$

Esham originally had employed by the Ottoman Empire (1299-1923) as financial certificates to pay the public debt in 1775 . The financial certificates served as the underlying for the government to gather taxes. ${ }^{18}$ The Ottoman Empire released these certificates to mobilize public funds to fulfill the requirement of the Treaty of Küçük Kaynarca after being defeated by Russia of 1768-1774. At that time, the Ottoman Treasury expropriated the amount of major tax farms, had them run by state agents and published shares for the forthcoming revenues. ${ }^{19}$

After the restoration of the public finance system had accomplished through the forming of the malikane structure, 80 years later, the condition in 1774 required a pressing reform again in public finance. ${ }^{20}$ By introducing the esham system in 1775, the Ottoman

Empire. University of Houston and National Bureau of Economic Research (NBER), December, 7.

${ }^{17}$ Çizakça, "Risk Sharing..., p. 193.

${ }^{18}$ COMCEC, The Role of Sukuk in Islamic Capital Markets (Ankara: The Standing Committee for Economic and Commercial Cooperation of the Organization of the Islamic Cooperation (COMCEC) Coordination Office, 2018), 9.

${ }^{19}$ Balla and Johnson, "Fiscal Crisis..., p. 839.

${ }^{20}$ Murat Çizakça, "Domestic Borrowing Without the Rate of Interest: Gharar and The Origins of Sukuk", Munich Personal RePEc Archive (MPRA) Paper, No. 23205 (2010), 12.

48| Copyright (C) 2021, IQTISHODUNA: Jurnal Ekonomi Islam

http:/ / ejournal.iaisyarifuddin.ac.id/index.php/iqtishoduna 
government was able to reduce its cost of borrowing from roughly $75 \%$ to the range of $10-20 \%$. But the real motive for introducing this system was to finance a war indemnity of 7,500,000 gruş to Russia within a year. $^{21}$

A comparative study indicates the fiscal policy of French rulers preferred to dedicate the restraint that prevented them from converting institutions than Ottoman sultans were by their relational liberty.22 French kings were more sturdily bonded to the existent set of fiscal instruments throughout the 18th century than their Ottoman counterparts. ${ }^{23}$ During the $16^{\text {th }}$ century, both countries made extensive use of tax farming to collect revenue, however, uncertain property rights caused by fiscal pressure led to different paths of institutional change in each state. In France, tax collectors successfully overcame the collective action costs of imposing constraint on the King. In the Ottoman Empire, tax collectors faced prohibitive transaction costs to organizing in a similar manner. ${ }^{24}$

Nevertheless, the uncertainty of property rights due to the fiscal tension induced the institutional change in diverse ways of each state. In 1783, the French Government was

${ }^{21}$ Murat Çizakça, Islamic Capitalism and Finance: Origins, Evolution, and the Future. (Cheltenham: Edward Elgar Publishing, 2011), 71. 840.

22Balla and Johnson, "Fiscal Crisis..., $p$.

${ }^{23}$ Ibid., p. 826.

${ }^{24}$ Ibid., p. 809. caught in a combustible spin of loan to overcome the existent debt. ${ }^{25}$ But the Ottoman Empire was able to reform the fiscal policies so as the short-term financial needs can be resolved. The reforms kept on into the 19th century through a new fiscal system which is known as esham. ${ }^{26}$

Hereinafter, the Ottoman Empire eventually was not able to boost sufficient revenue to meet its expenditure and it was obliged to pull out an enormous debt. ${ }^{27}$ In the absence of intermediary protecting lenders from the sultan's desire, the esham system was not able to produce the prominent fund to satisfy the necessity of the government until urge the government to take loans from abroad. In the early 1870s, the Ottoman Empire used around $60 \%$ of tax revenues to shell out the foreign debt. 28

However, esham previously did well in gathering one-third of the war indemnity obligations in less than a year. During 10 years since its initiation in 1785, esham accumulated revenue until 11,500,000 grus. The amount was more than fifty percent of the whole revenue of the state. If esham might generate the amount in

${ }^{25}$ Ibid., p. 838.

${ }^{26}$ Ibid., p. 839.

27Murat Çizakça, A Comparative Evolution of Business Partnerships: The Islamic World and Europe, with Specific Reference to the Ottoman Archives (Leiden, New York, Koln: Brill, 1996), 192.

${ }^{28}$ Andrew Wheatcroft, The Ottomans: Dissolving Images (London: Penguin, 1996), 188-193. 
10 years, so malikane needs 90 years to reach the same amount. ${ }^{29}$

In comparison to malikane, whereby the entire stream of revenue of a tax farm was auctioned off to the highest bidder for his lifetime, in esham, the tax farm was kept and managed by the state and the annual profit was divided into shares and each share was sold off. Once bought, the purchaser of a sehm, continuing to receive the same annual profit share for his lifetime. Therefore, it was probably the first ever securitization by an Islamic state of the actual annual profit of a tax source from customs revenue. ${ }^{30}$

Understanding the common mechanism of malikane system is beneficial to understand the reasons behind the emersion of esham system which capable to accomplish the failures of malikane system as fiscal and internal debt policies. Like iltizam, malikane, was contracted out by an auction mostly held in Istanbul. However, unlike iltizam, the contract in malikane system was for life-term and bids were made for a total down payment, called muaccele. ${ }^{31}$ Thus, the malikane was mixture of two previous taxation methods, timar, and iltizam. Its lifetime duration led to that contractors should have taken into consideration the future productivity of the tax

${ }^{29}$ Çizakça, "Risk Sharing..., p. 193.

${ }^{30}$ Çizakça, Islamic Capitalism, p. 71.

${ }^{31}$ Kadir Sarp Sök, An Analysis Study On The Implementations of Gedik, Esham And Muzara'a, A Master's Thesis Department of History İhsan Doğramacı Bilkent University, Ankara (2019), 31. sources, like a timar holder and its method of payment, namely muaccele, a large lump sum payment, and $m a l$, an annual rent, was similar to iltizam 32 . The system was introduced during a period of extreme financial hardship and severe budget deficits caused by the long and costly war with the Habsburgs and played a crucial role in restoring the State budget. ${ }^{33}$

Furthermore, iltizam in fact were the wide utilize of tax farming to gather revenue from the private enterprise in the Ottoman version. Then entrepreneurs were envoyed the right to take taxes. ${ }^{34}$ With a lot of uncertainty and there was risk transfer, iltizam carried a gharar component. Thus, the end result, the State did not get much revenue. ${ }^{35}$

Malikane can be considered as a system of risk sharing. The entrepreneur took a great risk and made a very large lump-sum payment up front. Now the risks were shared fairly if: (1) The entrepreneur lived a long life, he would make substantial profits, and the state would lose; (2) He lived a short life, the state could take back the tax-farm at his death and re-sell it again at a new auction making substantial profits. With such risk sharing, the gharar was eliminated as well. As a result of all this, the

${ }^{32}$ Ibid., p. 32.

${ }^{33}$ Murat Çizakça, "Ottoman Cash Awqaf Revisited: The Case of the Bursa 1555-1823", Foundation for Science Technology and Civilization, Publication ID: 4062 (June, 2004), 8.

${ }^{34}$ Çizakça, "Risk Sharing..., p. 192.

${ }^{35}$ Ibid., p. 193.

50| Copyright (C 2021, IQTISHODUNA: Jurnal Ekonomi Islam

http:/ / ejournal.iaisyarifuddin.ac.id/index.php/iqtishoduna 
government was able to increase its revenues by $1,400 \% .^{36}$

\section{MODUS OPERANDI OF ESHAM}

Hereinafter, esham organizes the incredible settlement for generating a fixed earning as well as the opportunity to liquidity in the investment sans friction with the interest forbidding. ${ }^{37}$ Esham should be respected as equity, not as debt. This is a very beneficial situation in regard to the gearing ratios of Basel III. Put differently, the issuer of esham would be capable to sustain the capital base without worsen the debt/equity ratio. ${ }^{38}$

Hence, it can be resumed that esham were based on the assets put aside by the issuer that are still owned and managed by the issuer. The issuer allocates just a some fraction of the yearly earning for esham. ${ }^{39}$ The simpleness of esham in contrast to traditionary sukuk structures that will reduce the cost to a municipal issuer who would otherwise find a sukuk offering not cost competitive due to small issuance sizes across which the added structuring costs can spread. In esham, the lack of ownership transfer (beneficial or full legal

36Ibid., p. 193.

${ }^{37}$ Musari, Esham for, p. 4.

${ }^{38}$ Murat Çizakça. Can There be Innovation in Islamic Finance? Case Study: Esham, a paper was presented at the 11th IFSB Summit, Knowledge Sharing Partner Session: "New Markets and Frontiers for Islamic Finance: Innovation and the Regulatory Perimeter" in Mauritius (May 20, 2014a), 5.

${ }^{39}$ Musari, Esham for, p. 5. ownership) of an asset contributes to reducing the amount of additional documentation than sukuk. ${ }^{40}$

Certainly, sukuk is a greatly fruitful model of financial engineering using historical instruments. Sukuk portrays the modernity of two historical instruments, namely cash waqf and esham. ${ }^{41}$ Therefore, there is a slice between sukuk and esham because esham is one of the ingredients of sukuk.42 The sale-lease backrepurchase technique which frequently utilized in most sukuk alijara from the beginning was employed in the Ottoman cash waqf. The special purpose vehicle (SPV), the pivotal side of each sukuk, in fact merely a simple cash waqf. Regarding securitization, that is the concept of separating a revenue flow into the same parts to be offered for sale to the public, actually esham. ${ }^{43}$ Thus, esham actually the origin of sukuk $^{44}$ and constituted the very first Islamic securitization. ${ }^{45}$

How to ensure that esham complies with sharia principles? First, the conditions of financial transaction might be considered as

${ }^{40}$ Daniel Hummel and Blake Goud, "An Esham-Ijara Structure in the United States?", in Journal of Islamic Accounting and Business Research, Vol. 8, No. 4 (2017), 460.

${ }^{41}$ Murat Çizakça, Finance and Development in Islam: A Historical Perspective and a Brief Look Forward, in Zamir Iqbal and Abbas Mirakhor (Eds.)., Economic Development and Islamic Finance (Washington: World Bank, 2011), 145.

${ }^{42}$ Musari, Esham for, p. 4.

${ }^{43}$ Çizakça, Finance, p. 145.

${ }^{44}$ Çizakça, Domestic, p. 14.

${ }^{45}$ Ibid., p. 15. 
riba, if take place: (1) Excess or surplus over and above the loan capital to be returned to the lender; (2) Determination of this surplus in relation to time with a definite date of redemption; (3) Stipulation of this surplus in the loan agreement. With regard to the life time esham, the uncertainty of the lifespan of the investor eliminates the certainty of the surplus and violates, at once, all three conditions. With regard to the perpetual esham, the lack of a definitive date of redemption and the fact that redemption is at the discretion of the borrower, not the lender, violates the first and the second conditions. Thus, it is concluded that esham is not usurious. ${ }^{46}$ Second, while esham shares are sold by an investor in secondary markets, the price will be determined by supply and demand as well as the past payment performance of the annuities. This will render esham a true profit or loss sharing instrument. Moreover, with the redemption being at the discretion of the borrower/issuer, risks are not shifted by the lender upon the borrower. Instead, a compromise is reached by which while the issuer/borrower redeems his debt at his discretion, the investor obtains the right to a fixed and regular income for as long as the issuer/borrower does not redeem. Meanwhile, the investor can sell esham at the stock exchange at market prices. Thus we conclude, esham is not a risk shifting

\footnotetext{
${ }^{46}$ Çizakça. Can There, p. 5-6.
}

instrument. Thus, esham is not a risk shifting instrument. ${ }^{47}$ Third, esham influences one of the components of maqasid al shari'a positively without influencing any of the others negatively so that esham bring one step nearer to the Al-Ghazali/AlShatibi Optimum. ${ }^{48}$

Regarding the integration of cash waqf and sukuk, which has recently become an innovation in Islamic financial engineering, it turns out that there are things which contradictory when viewed from a historical point of view,

".....cash waqf and sukuk combination is not something I agree upon. This is for two reasons: (1) Every sukuk must have a redemption date which means that funds collected by sukuk to establish a cash waqf must be relinquished and paid back to investors at a particular predetermined date, which makes waqf a temporary one; (2) Consider temporary waqf an aberration, even a corruption of this glorious institution." 49

In short, a waqf should not be established with borrowed money. If it is desired to establish this waqf with global funds, in itself an excellent idea, the need arises to do this with an instrument that does not have to be paid back. As it is well known, such an instrument exists and it is called esham. ${ }^{50}$ Any attempt to combine waqf, a genuine Islamic institution that has superbly served Islamic World for centuries, with

\footnotetext{
${ }^{47}$ Ibid., p. 6.

${ }^{48}$ Ibid., p. 7.

${ }^{49}$ Personal explanation by Murat Çizakça, September 10, 2020.

${ }^{50}$ Çizakça, Merging, p. 103.
}

52| Copyright (C) 2021, IQTISHODUNA: Jurnal Ekonomi Islam http:/ / ejournal.iaisyarifuddin.ac.id/index.php/iqtishoduna 
sukuk, is tantamount to corrupting it. Such a combination should not be permitted. If the ultimate aim is to mobilize global funds to finance waqf, in itself an excellent idea, then the correct instrument of choice should be esham. ${ }^{51}$

For this reason, the scheme which combining waqf and sukuk instruments needs to be corrected,

"....people are always in a hurry and prefer the easiest route for them. Consequently, they also make huge mistakes. Combining waqf and sukuk is an excellent example for such a mistake. If they go ahead with this project, they will kill the waqf with their own hands! So, it is incumbent upon us to warn them to the best of our abilities and then leave the rest to Allah, who knows best." 52

Lastly, regarding the modus operandi of esham in the Ottoman Empire generally can be explained as follows,

"In this system, the state set aside an asset, which yielded a regular annual revenue. It then allocated a certain fraction of this revenue for esham. This revenue fraction was then securitized into equal shares and offered for sale to the public. Each share authorized its purchaser, the investor, to receive his share of the allocated annual revenue pro rata. This was a fixed amount. The investor received his annuity for as long as he lived. Each share was sold at a certain multiple of the annuity it was to yield to the investor. Usually, the price of a share was determined as 5 to 12

\footnotetext{
51Ibid., p. 110.

52Personal explanation by Murat Çizakça, Januari 28, 2021.
}

times the annuity it yielded. Once bought, each sehm was negotiable and could be sold in secondary markets." 53

Regarding the modus operandi of esham for today, an interdisciplinary team which involves two economic/financial historians, several scholars of figh mu'amalah, and a professor of finance at INCEIF University have modernized it based on the historical precedence. ${ }^{54}$

\section{ESHAM IN FACING THE CRISIS}

In the financial crisis, esham might intensify the fiscal capacity. If the conventional instrument keeps the budget deficit by bearing money creation which enlarges the base money in the economy, esham performs by managing funds unaccompanied by the money creation. This is exactly the heart of the Islamic economics role that sustains the stability of the economy by avoiding money creation but heading money velocity. The money creation will bring the matter of escalating the price of goods/services and by turns will impose the state budget. .55

By using the Concept of Investment-Saving (IS) and Liquidity-Money (LM), esham may influence the sustainable economic development. Esham can work hand in hand for monetary-fiscal activities. In the long term, because esham funds are channeled to activities in the real sector to finance productive or social projects, they will

\footnotetext{
${ }^{53}$ Çizakça, "Risk Sharing..., p. 193.

${ }^{54}$ Çizakça, Can There, p. 2.

${ }^{55}$ Musari, Esham for, p. 7.
} 
contribute to decrease the inflation and prevent the crisis of economy ${ }^{56}$ as shown Figure 1.

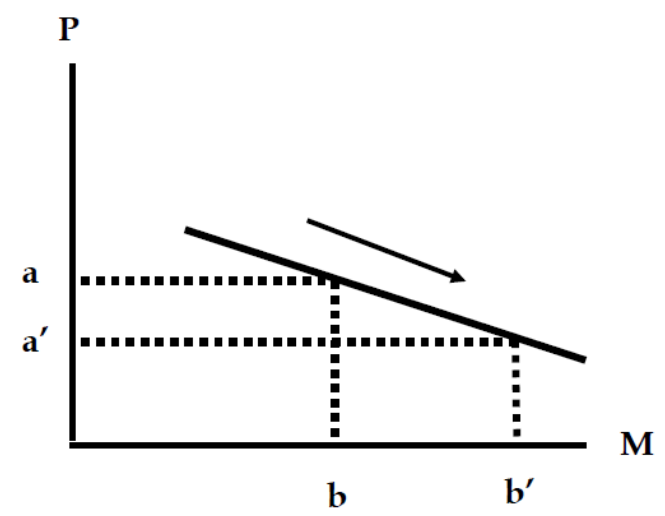

Figure 1. Implication of Esham in Preventing the Crisis

Similarly, esham also serve a good device to call up a public fund because incorporate the risk-sharing, investment cooperation, and engagement of assets or project as the underlying of issuance. This is a better choice than looking for a foreign debt. 57

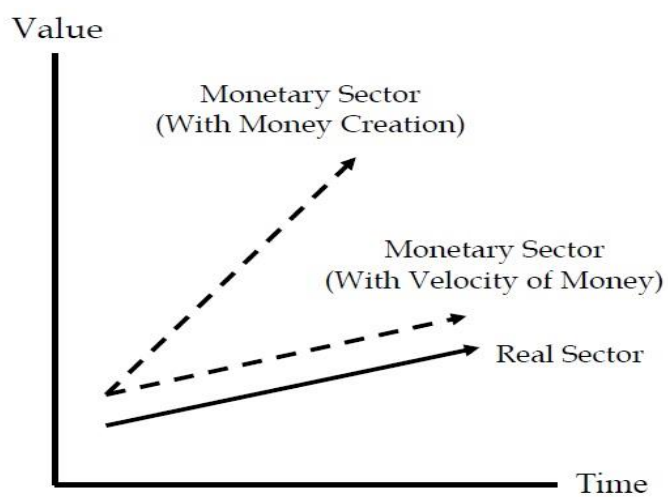

Figure 2. Implication of Esham in Real Sector and Monetary Sector

In order to comply with the Islamic economics principle, as a part of Islamic financial instruments, esham have a character as the instrument of wealth distribution and equalization by managing the excess and lack of liquidity ${ }^{58}$ so as the monetary sector will be in line with the real sector by putting forward the velocity of money and leave the money creation as shown in Figure 2.

Lastly, how can esham affect the economy during a crisis? When a crisis occurs, the presence of esham becomes the fiscal policy in which the funds are used by the government to intervene in the economy.

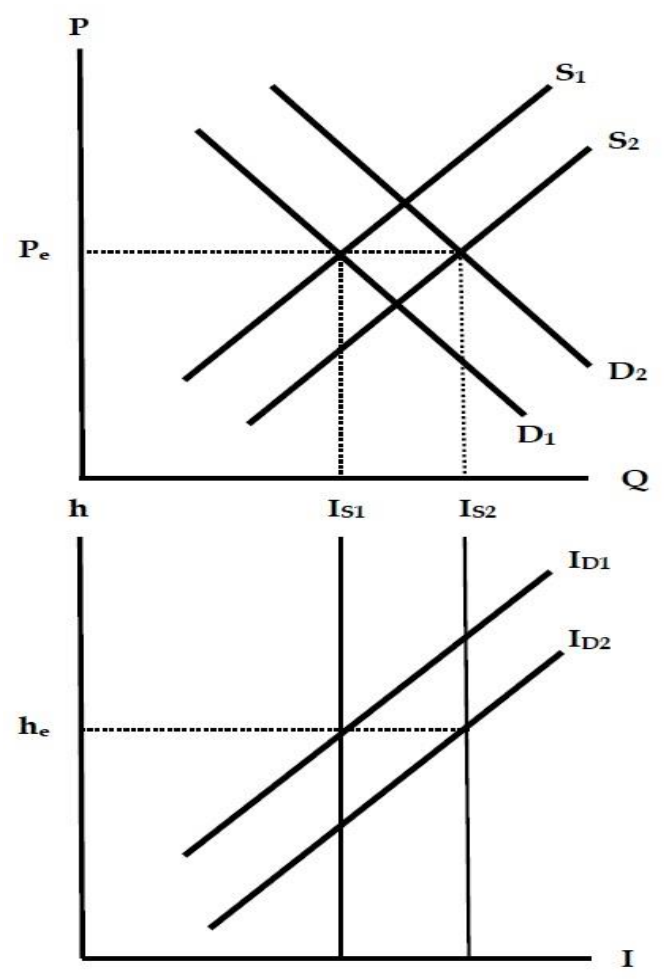

Figure 3. Mechanism Esham Affect the Market

Theoretically, the allocation of esham funds to the real sector will

\footnotetext{
${ }^{56}$ Ibid., p. 7.

${ }^{57}$ Ibid., p. 6.
}

58 Ibid., p. 6.

54| Copyright $\odot$ 2021, IQTISHODUNA: Jurnal Ekonomi Islam http://ejournal.iaisyarifuddin.ac.id/index.php/iqtishoduna 
help the government drive the economy as well as control prices in the market for goods and services. When the demand for goods and services increases $\left(D_{1} \rightarrow D_{2}\right)$, the price will increase in the short run. In turn, this will drive the business sectors ( $\mathrm{I}_{\mathrm{S} 1} \rightarrow \mathrm{I}_{\mathrm{S} 2}$ ). When the business sectors experience recovery as reflected by an increase in total revenue, this will encourage an increase in the supply of goods and services $\left(S_{1} \rightarrow S_{2}\right)$. Also, it will boost the profit expectations (h) of investors for investing in esham ( $\mathrm{I}_{\mathrm{D} 1}$ $\left.\rightarrow \mathrm{I}_{\mathrm{D} 2}\right)$. Overall, the mechanisms of esham affect the economy during the crisis shown by Figure 3.

Further, the esham scheme for fiscal sustainability may adopt the modernized esham model by interdisciplinary team of scholars at INCEIF University. ${ }^{59}$ If the issuer is a government, certain taxes can be allocated by law to the payment of annuities, or one branch of a government may provide guarantee for the other. The former, of course, would be a far more persuasive alternative. If it is a private corporation, a reliable and trustworthy third party may need to be found. Third party guarantee pertains to the fixed annuities only. ${ }^{60}$

Therefore, to deal with a crisis triggered by a pandemic, esham as a financial instrument in overcoming the crisis caused by the defeat of war and debt in the history of Islamic

${ }^{59}$ Murat Çizakça. "Proposal for Innovation in the Capital Markets: Esham", in Global Islamic Finance Report (2013b), 91.

${ }^{60}$ Ibid., p. 92. civilization have the potential to be developed. As the origin of sukuk in the past, esham can be an alternative of sukuk for today. Esham have simpler structures than sukuk which can be used at a lower cost.

\section{CONCLUDING REMARKS}

Esham actually is not a new instrument in Islamic finance. In the past, esham had been used by the Ottoman Empire to mobilize a massive amount of money from the public rapidly in a relatively short time. Esham proved effective for the government to raise the low-cost fund. Besides a simpler instrument than sukuk, the modernized esham may generate a fixed income for the investor and can be liquidity for the government with complying the sharia. Esham has a distinctive redemption structure and ideal for raising capital without deteriorating the gearing ratios because esham would be considered not as debt but as equity. Esham has no obligation to return the principal fund. At this level, esham has the opportunity to prevent crisis and managing the excess and lack of liquidity by putting forward the velocity of money so as the monetary sector will be in line with the real sector. During crisis, the government may intervene in the economy through esham. Esham funds to the real sector in turn will help the government drive the economy as well as control prices in the market for goods and services. Wallahua'lam bish showab. 


\section{REFERENCES}

Balla, Eliana., and Johnson, Noel D. 2009. Fiscal Crisis and Institutional Change in the Ottoman Empire and France. The Journal of Economic History, Vol. 69, No. 3, September, 809845.

Birdal, Murat. 2010. The Political Economy of Ottoman Public Debt, Insolvency and European Financial Control in the Late Nineteenth Century. London: Tauris Academic Studies.

Çizakça, Murat. 1996. A Comparative Evolution of Business Partnerships: The Islamic World and Europe, with Specific Reference to the Ottoman Archives. Leiden, New York, Koln: Brill.

Çizakça, Murat. 2000. A History of Philanthropic Foundations: Islamic World from the Seventh Century to the Present (Istanbul: Bogazici University Press).

Çizakça, Murat. 2004. Ottoman Cash Waqfs Revisited: The Case of Bursa 1555- 1823. Publication ID 4062, The Foundation for Science, Technology and Civilisation (FSTC), Manchester.

Çizakça, Murat. "Democracy, Economic Development and Maqasid al-Shari'ah", Review of Islamic Economics, Vol. 11, No. 1 (2007), 101-118.

Çizakça, Murat. 2010. Domestic Borrowing Without the Rate of
Interest: Gharar and The Origins of Sukuk. Munich Personal RePEc Archive (MPRA) Paper No. 23205.

Çizakça, Murat. 2011. Islamic Capitalism and Finance: Origins, Evolution, and the Future. Cheltenham: Edward Elgar Publishing.

Çizakça, Murat. 2012. Finance and Economic Development in Islam, Historical Perspective. Munich Personal RePEc Archive (MPRA) Paper No. 42046, October 18.

Çizakça, Murat. 2013a. Finance and Development in Islam: A Historical Perspective and a Brief Look Forward. In Iqbal, Zamir, and Mirakhor, Abbas. (Eds.). Economic development and Islamic finance (pp. 133147). Washington, DC: The World Bank.

Çizakça, Murat. "Proposal for Innovation in the Capital Markets: Esham", Global Islamic Finance Report (2013b), 91-93.

Çizakça, Murat. Can There be Innovation in Islamic Finance? Case Study: Esham, A paper was presented at the 11th IFSB Summit, Knowledge Sharing Partner Session: "New Markets and Frontiers for Islamic Finance: Innovation and the Regulatory Perimeter" in Mauritius (May 20, 2014a).

56| Copyright (C 2021, IQTISHODUNA: Jurnal Ekonomi Islam http://ejournal.iaisyarifuddin.ac.id/index.php/iqtishoduna 
Çizakça, Murat. "Risk Sharing and Risk Shifting: An Historical Perspective", Borsa Istanbul Review, Vol. 14, No. 4 (2014b), 191-195.

Çizakça, Murat. "Merging Waqf and Sukuk", Journal of Islamic Economics, Banking and Finance, Vol. 12, No. 3 (JulySeptember, 2016a), 98-111.

Çizakça, Murat. 2016b. Merging waqf and sukuk: Should we or shouldn't we? Incomplete paper submitted (in absentia) at the Global Waqf Conference, September 2016 in Swansea, UK.

COMCEC. 2018. The Role of Sukuk in Islamic Capital Markets. Ankara: The Standing Committee for Economic and Commercial Cooperation of the Organization of the Islamic Cooperation (COMCEC) Coordination Office.

Hummel, Daniel, and Goud, Blake. 2017. An Esham-ljara Structure in the United States?" Journal of Islamic Accounting and Business Research, Vol. 8, No. 4, 455467.

Kalemli-Ozcan, Sebnem. 2007. Financial Development, Institutions, and Growth: Historical Evidence from the Ottoman Empire. University of Houston and National Bureau of Economic Research (NBER), December.
Musari, Khairunnisa. “The Evolution of Waqf and Sukuk toward Sukuk-Waqf in Modern Islamic Economy", International Journal of 'Umranic Studies, Vol. 2, Issue 1 (January, 2019a), 45-54.

Musari, Khairunnisa. 2019b. Esham for Fiscal Sustainability, An Alternative to Sukuk in Islamic Finance Perspective: Historical Experience. A paper was presented at Researcher Day 2019 "The 2019 International Conference on Fiscal Policy and Input-Output Modeling" at Auditorium of Fiscal Policy Agency Building, Ministry of Finance, Jakarta, August 28th29th.

Musari, Khairunnisa. 2020. Cash Waqf Linked Sukuk, A New Blended Finance of Fiscal Instrument for Sustainable Socio-Economic Development: Lesson Learned from Indonesia. A paper was presented at 12th International Conference on Islamic Economics and Finance (ICIEF) "Sustainable Development for Real Economy" with hosted by Istanbul Sabahattin Zaim University (IZU) and jointly organized by Islamic Research and Training Institute (IRTI) Islamic Development Bank (IDB) and International Association of Islamic Economics (IAIE) with the collaboration of Statistical, Economic and Social Research and Training Centre for 
Islamic Countries (SESRIC) and Hamad Bin Khalifa University, Istanbul, June $14^{\text {th }}$ $20^{\text {th }}$.

Özbek, Nadir. 2018. “Tax Farming in the Nineteenth-Century Ottoman Empire: Institutional Backwardness or the Emergence of Modern Public Finance?", The Journal of Interdisciplinary History, Vol. 49 , No. 2, 219-245.

Sök, Kadir Sarp. 2019. An Analysis Study On The Implementations of Gedik, Esham And Muzara'a, A Master's Thesis Department of History İhsan Doğramac1 Bilkent University, Ankara.

Wheatcroft, Andrew. 1996. The Ottomans: Dissolving Images. London: Penguin.

Zen, Fauziah and Fukunari Kimura. 2020. Maintaining Fiscal Sustainability During the Pandemic Crisis. Economic Research Institute for ASEAN and East Asia (ERIA) Policy Brief No. 2020-04, June.
Newspapers/Magazines/Internet

Adil, Mustafa. 2020. 2020: A strong year for Sukuk. Refinitiv, Investment Insight, October 19th. Retrieved from https://www.refinitiv.com/p erspectives/future-ofinvesting-trading/2020-astrong-year-for-sukuk/

Akhlas, Adrian Wail. 2020. Govt raises $\$ 2.5 \mathrm{~b}$ through global sukuk offering to address pandemic deficit. The Jakarta Post, June $18^{\text {th }}$. Retrieved from https://www.thejakartapost.c om/news/2020/06/18/govtraises-2-5b-through-globalsukuk-offering-to-addresspandemic-deficit.html.

Fitch Ratings, Sukuk Volumes Resilient to Coronavirus Stress, Fitch Ratings, Islamic Finance (October 21, 2020). Retrieved from

https://www.fitchratings.com /research/islamicfinance/2020-sukuk-volumesresilient-to-coronavirus-stress21-10-2020

58| Copyright (C 2021, IQTISHODUNA: Jurnal Ekonomi Islam http://ejournal.iaisyarifuddin.ac.id/index.php/iqtishoduna 